\title{
A Comparative Study on Environmental Flows Assessment Methods in Lower Reach of Mahanadi River
}

\author{
Sangitarani Sahoo(M. Tech Scholar) Deepak Khare(Prof \& Head, WRDM) \\ Prabhash K Mishra(Research Scholar) Satyapriya Behera (M. Tech Scholar) \\ Radha $\operatorname{Krishan}^{5}$ (Research Scholar) \\ Water Resources Development and Management, IIT Roorkee
}

\begin{abstract}
Environmental flows assessment is a process which determines the allocated water for maintaining aquatic habitats and ecological processes in a environment. The river system attains zero flow in low flow period due to construction of hydropower generating structures, water retaining structure and withdrawal of water by water users, which possesses a tremendous threat to the environment, ecology $\&$ aquatic life. Therefore a need arises to regulate the reservoirs for releasing the adequate water in the river throughout the year as well as a flushing flow once in a year. Thus environmental flows assessment is done in Lower Mahanadi sub-basin and recommended to provide the EFRs on average $26 \%$ of MAF with a range of Low flow $56 \%$ of mean low flow \& High flow $21 \%$ of mean high flow to be ensured at any circumstances to avoid any degradation of river ecosystem. In the present study the assessment of the environmental flows on the basis of Tennant method, Tessman method, VMF method, Q90_Q50 method, Smakhtin method, low flow index (7Q10) method and FDC (EMC shifting technique) method using Global Environmental Flow Calculator (GEFC) software.
\end{abstract}

Keywords: EFR, GIS, Tennant, Tessman, VMF, Q90_Q50, 7Q10, FDC method.

\section{Introduction}

The environmental flows assessment (EFA) methodologies began in USA in the late 1940s and picked up during the 1970s. Outside the USA, the development of EFA methodologies gained in significant ground in 1980s or later. In India the issue of minimum flows was first highlighted in a judgement of Supreme Court of India in $1999 \&$ it is directed the Government to ensure a minimum flow of $10 \mathrm{~m} 3 / \mathrm{sec}$ in the Yamuna river for improving its water quality. In 2001, the Govt of India constitute the Water Quality Assessment Authority (WQAA), which constituted a working group (WG) in 2003 \& to advice the WQAA to release a 'minimum flow' in rivers for the conservation of ecosystem.

Environmental flow can be described as the quantity, quality \& timing of water flow required to sustain freshwater and estuarine ecosystem and human livelihoods that depend on these ecosystem by Brisbane Declaration (2007), which made by more than 800 delegates from 50 nations . Environmental flows assessment is a process which determines the allocated water for maintaining aquatic habitats and ecological processes in a desirable state i.e. Instream flow requirements (IFRs), Environmental flow requirement or Environmental water demand (Davis and Hirji 2003, Dyson et al 2003, Lankford 2002, Smakhtin et al. 2004). Environmental flow are different from Natural flow and seldom to be 'Minimum flow'. Adequate environmental flow are not only the characteristics of a healthy river, however the reduction of pollution and control of instream activities like fishing and recreation are the requirements of healthy river. Therefore environmental flow should be considered as an integral part of the modern management of river basin. The flow with high magnitudes are important for preservation of channel and vegetation. The moderate flows are needed for fish passage and for removing organic substances from river coasts. The flow with low magnitudes are important for regulation of algae \& conservation of water quality. The people including policy makers, planners, economist, environmentalist, nonGovernment organisation, consumptive water use lobby groups, river communities, Hydrologists, Engineers, lawyers, needs for maintaining essential environmental flow.

\section{Environmental flow requirement}

Environmental flow requirement is the water that is left in a river or released from a reservoir, in order to maintain valued features of ecosystem (Tharme \& King 1998), renewal natural resources production system \& associated livelihood. One can say EFR is compromises of water resources development \& maintenance of a river in ecologically acceptable condition. Environmental flow requirement mainly takes two fundamentally different approaches depending on the objective in question:

How much water does a given ecosystem condition need ?

How much water does society allocate to ecosystem?

Is the allocated water is sufficient to maintain ecosystem?

Necessity of an Ecological Reserve

Water occurs within ecosystem, from source to sea \& the components of which are interrelated. Such as the surface \& related underground water, the channel, in stream biota, riparian plants and animals, transported sediment and natural chemicals etc. 
(I) Healthy aquatic ecosystems provide human several important silent services such as retention, storage \& consequent supply of water, the dilution, removal and purification of wastes.(II) Aquatic ecosystem also supply commercial and subsistence products i.e. fish \& plants.

\section{Review of Environmental flows assessment methods:}

In a comprehensive study of Environmental flow methodologies Tharme (2003) documented the existence of more than 207 Environmental Flow Methods (EFMs) in 44 countries \& it classified these into four general categories: hydrological methods; hydraulic rating methods; habitat simulation methodologies; holistic methodologies. These methods were mainly developed after studies have been conducted for rivers, wetlands, estuaries, forest and grassland ecosystem.

\subsection{Hydrological methods}

Hydrological approaches have been developed for broad scale planning \& which are fully dependent on the historical flow records. Among all these methods the best known method is Tennant method (1976), which defines seven classes ranging from severe degradation to outstanding ecological condition. According to Tennant classification a different percentage of the annual flow is allocated during the high flow periods and low flow periods. The Tessman method (1980) another EF method which depending on the different flow season (high, intermediate, low flow months). The low flow index method usually based on annual minimum flow thresholds i.e. 7Q10 (the lowest flow that occurs for seven consecutive days once in ten years) .The EFR can also be calculated using Range of Variability Approach (RVA), which evaluates flow regime based on a comparison of 33 flow statistics for the regulated as well as natural flow regimes. The other hydrological methods are based on FDC (EMC shifting technique) method through Environmental Global Flow Calculator software. The EFR is calculated by using 17 fixed probabilities and aim to maintain an ecosystem for default EMC classes varied from natural condition to critical modified condition of river.

Hydrological methods are typically inexpensive, rapid \& desktop approaches. They are highly appropriate at the reconnaissance level of water resources development and for planning purposes, providing routine and low resolution estimates of quantities to be set aside for environmental maintenance.

\subsection{Hydraulic rating methods}

Hydraulic rating methods ( termed by Loar et.al 1986) are used at a local scale, when river cross section measurements are available at each river section. In this method consider site specific information on hydraulic parameters, such as wetted perimeter or other limiting river cross section. The recommended flows are commonly set at a break point in the hydraulic parameter-discharge curve, interpreted as the flow below which habitat decreases rapidly with a decrease in flow $\&$ above which habitat increases slowly with an increase in flow.

\subsection{Habitat simulation methodologies}

These are based on the simulation of physical habitats, such as the instream Flow Incremental Methodology (Bovee,1982). These methods are an extension of the hydrological methods. It uses hydraulic condition, which meet specific requirement of biota for determining flow requirement. These methods use to find a relation between different flow regimes and the habitat quality requirements of fish species.

\subsection{Holistic methodologies}

The fourth methodologies labelled "holistic" have appeared more recently as a response to a changing conception of water resources management. This method considers the whole riverine ecosystem. In this method the Environmental flow requirement is maximum depth across riffle or other limiting river cross section. The recommended flows are commonly assessed for all biotic and abiotic components of river ecosystem. It is not only focuses on the rivers physical features but also the wetland, estuaries and ground water which are associated to the rivers ecosystem. The Building Block Method is a well documented method in Holistic methodologies for estimating EFRs at either the local or basin scale (King \& Louw, 1998; King \& Brown, 2003; Tharme,2003;) . The flow blocks encompass low flow \& high flow and both of are defined for normal \& dry years .

\section{Material \& method \\ Study area}

The Mahanadi is one of the major east flowing river of the country \& it is originating from Dhamtari district. The basin is broadly divided into three sub basin i.e. Mahanadi upper sub-basin, Mahanadi middle sub-basin, Mahanadi lower sub-basin. The Mahanadi river basin lies between $80^{\circ} 28^{\prime}$ to $86^{\circ} 43^{\prime}$ East longitude $\& 19^{\circ} 8^{\prime}$ to $23^{\circ} 32^{\prime}$ North latitude. The total length of the river is $851 \mathrm{~km}$ from origin to Bay of Bengal. The Mahanadi basin extend over five states i.e. Chhattisgarh (52.42\%), Odisha (47.14\% which is approximately catchment area 65847 Sq Km \& length $494 \mathrm{Km}$ ) \& smaller portion of Jharkhand, Maharashtra \& M.P. with total catchment area of 
139681.51 Sq Km. The basin have maximum length $587 \mathrm{~km} \&$ width have $400 \mathrm{~km}$ respectively. The Mahanadi Delta extends about $101 \mathrm{~km}$ lies in the Mahanadi basin. The annual rainfall of the Mahanadi catchment is about $1417 \mathrm{~mm}$. The three major tributaries are the Seonath, IB , Tel \& others are Jonk, Hansdeo, Mand, Ong. The main distributaries are Birupa, Kathajodi and others are Paika, Luna, Chitrotpala, Kuakhai, Devi, Bhargavi, Daya, Biluakhai, Kandal, Kushabhadra. The lower Mahanadi basin compromises an area $57958 \mathrm{Sq} \mathrm{Km}$. The longest Dam is named as Hirakud Dam $\left(21^{\circ} 32^{\prime} \mathrm{N}, 83^{\circ} 52^{\prime} 30^{\prime \prime} \mathrm{E}\right)$ of $4800 \mathrm{~m}$ length, which was constructed in 1957 across Mahanadi river near Sambalpur and the longest barrage is named as Mahanadi barrage of $1928 \mathrm{~m}$ length, which was constructed in 1991 across Mahanadi river at Jobra . In the present study the gauge station at Jobra of Mahanadi river is taken for the analysis of Environmental flow assessment. The thematic map of lower Mahanadi sub-basin \& its sub watersheds (Figure-1) are generated using Arc GIS 10.2.2 software.

\section{Description of the Hydraulic features of study area}

For the assessment of Environmental flows, the daily discharge data of Mahanadi river has used in this study. The flow regimes of the study area were analysed using several hydrological indicators (Table-1) i.e. Base Flow Index $(\mathrm{BFI})=((\mathrm{Q} 90) / \mathrm{MAF})--(\mathrm{Eq}-1)$

\& Hydrological Variability Index $(\mathrm{HVI})=((\mathrm{Q} 25-\mathrm{Q} 75) / \mathrm{Q} 50) \quad---($ Eq-2). Where Q90,Q75,Q50,Q25 are the annual flows equalled or exceeded for $90 \%, 75 \%, 50 \%, 25 \%$ of the time respectively, MAF = Mean annual flow and $\mathrm{MMF}=\mathrm{Mean}$ monthly flow. The higher the variability index, the more variable in river flow regimes.

Table-1: Hydraulic features of flow of the study area.

\begin{tabular}{|l|l|l|l|l|l|l|l|}
\hline $\begin{array}{l}\text { Study } \\
\text { area, } \\
\text { River }\end{array}$ & $\begin{array}{l}\text { Geograp-hical } \\
\text { location }\end{array}$ & $\begin{array}{l}\text { MAF } \\
\left(\mathrm{m}^{3} / \mathrm{sec}\right)\end{array}$ & $\begin{array}{l}\text { Low flow-High } \\
\text { flow range } \\
\left(\mathrm{m}^{3} / \mathrm{sec}\right)\end{array}$ & BFI & HFI & $\begin{array}{l}\text { No. of L F No. of H F } \\
\text { months i.e. } \\
\text { MMF }<0.4 \\
\text { MAF }\end{array}$ & $\begin{array}{l}\text { MMF }>0.8 \\
\text { months i.e. } \\
\text { MAF }\end{array}$ \\
\hline $\begin{array}{l}\text { Jobra, } \\
\text { Mahanadi }\end{array}$ & $\begin{array}{l}20^{\circ} 28^{\prime} \mathrm{N} \\
85^{\circ} 54^{\prime} \mathrm{E}\end{array}$ & 741 & $142-1940$ & $5 \%$ & 2.92 & 8 & 4 \\
\hline
\end{tabular}

\section{Method}

Environmental flow Researchers have stated the hydrological methods based on morphology, ecology \& location of rivers are very successful in application. Hence the commonly methods are used in this study for estimation of Environmental flow. The Tennant method assumes, some proportion of the average / mean Annual flow (MAF) is required to sustain the biological integrity of a river ecosystem. Tennant (1976) recommended percentage values of MAF for 'low' \&' high' flow season and a periodic flushing flow of $200 \%$ of the MAF. Looking into the importance of the flow variability in the river system, the constant allowance for environmental flow based on the mean annual flow (MAF) will be not adequate for the Indian River system which has a large variation in the flow during the monsoon and non-monsoon periods. According to Tessman in 1980 modified the Tennant's Method to include a more detailed monthly variation of environmental flow. 

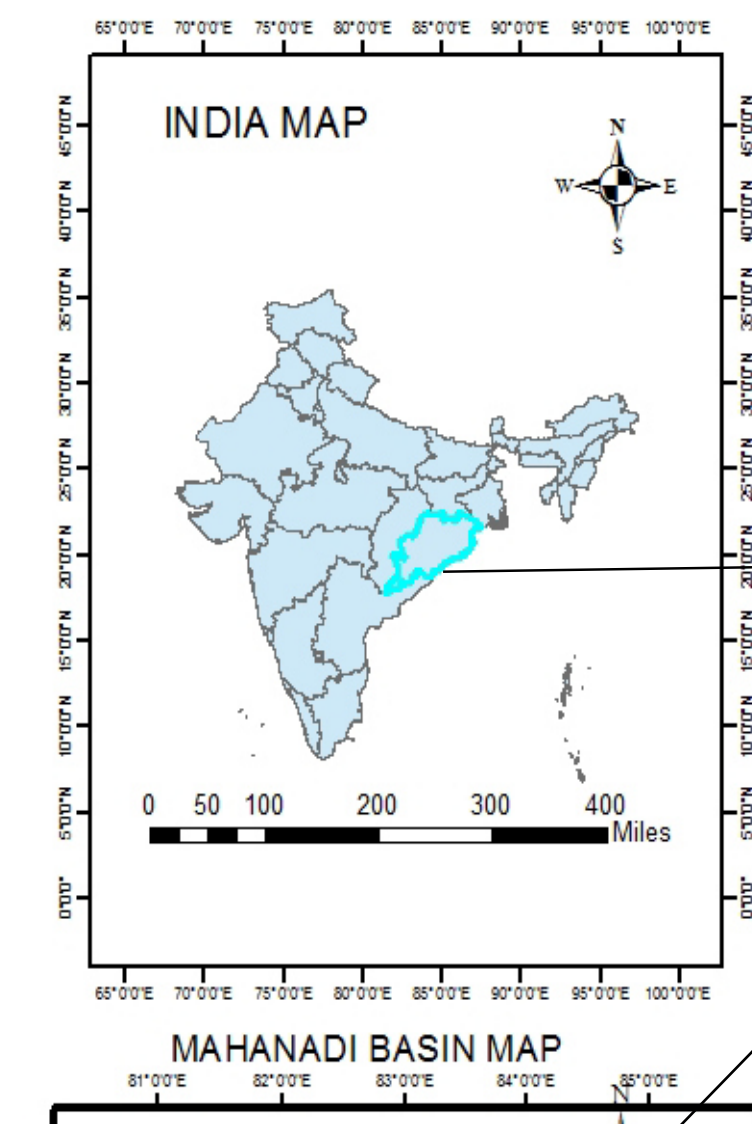

\section{LOWER MAHANADI SUB-BASIN MAP}

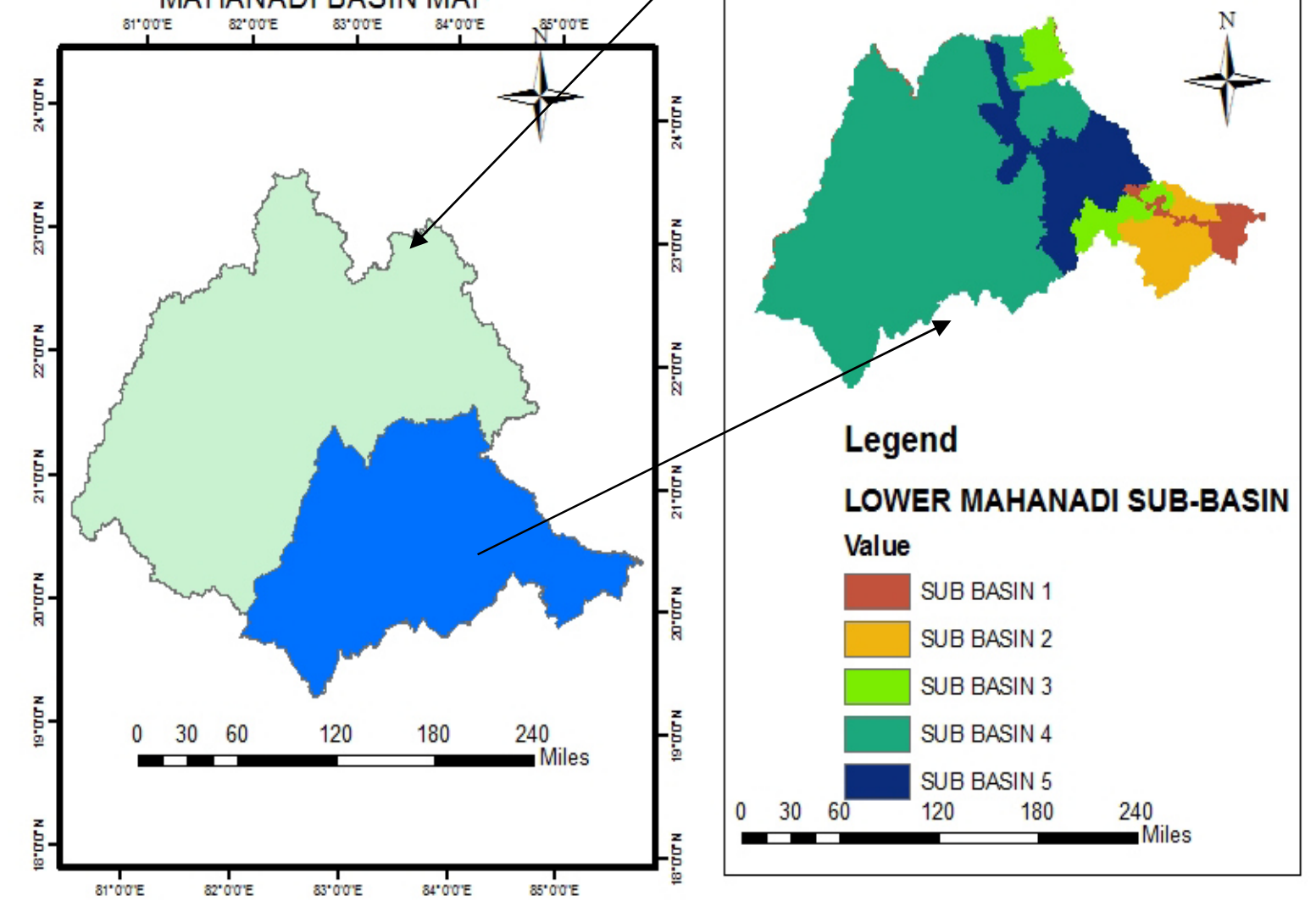

Figure 1:Location map of study area

The low flow index( 7Q10) method (Jha, R. 2008) is interpreted as the 7day low flow with a 10 year return period using daily discharge data. This method has been applied in various countries as the 7Q10 use for flow regulation purposes, ranging from protection or regulation of water quality from waste water discharges or 
waste load allocation. Also determine the minimum stream flow for the habitat protection during drought condition. Smakhtin et al.(2004) has defined four potential ecological river statuses for application within global hydrological model, following the recommendations of the DWAF,1997. The Q50 for good ecological status,Q75 for moderate ecological status \& Q90 for fair condition as well as the base flow requirement. The Q90_Q50 method (A.V. Paster et al., 2014) is based on the annual flow quantiles which is uses as to allocate the minimum instream flow during the high-flow season and low-flow season. The minimum flow (EFR) threshold Q90 during the low flow season \& Q50 during the high flow season respectively (Table-2). The VMF method (A.V. Paster et al., 2014) based on the average monthly flows. In this method the intermediate flow is determined between the high flow \& low flow months and uses as to develop the increase in the protection of fresh water ecosystems during the low flow season with a reserve of $60 \%$ of the MMF \& a minimum flow of $30 \%$ of MMF during the high flow season. This method also allows other water users to withdraw water upto $40 \%$ of the MMF during the low flow season.

Flow Duration Curve (FDC) method is developed by Smakhtin and Anupthas (2006).

There are four subsequent steps to evaluate Environmental Flow (EF). Such as (a)simulating reference hydrological conditions with 17 fixed percentage points on the probability axis are $0.01,0.1,1,5,10,20,30,40$, 50, 60, 70, 80, 90, 95, 99, 99.9 \& 99.99\%. (b)Defining environmental management classes (EMCs A, B, C, D, E \& F). (c)Establishing environmental FDCs from reference condition.(d) Simulating continuous monthly time series of EFs. The mentioned 17 percentage points are to be used as steps in this shifting procedure. The FDC shift by one step means, flow which was exceeded 99.99 percent of the time in the original FDC will be exceeded 99.9 percent of the time. The flow at 99.9 percent becomes the flow at 99 percent, the flow at 99 percent becomes the flow at 95 percent etc. The entire shifting procedure can be accomplished in a spreadsheet.

Table-2: Description of hydrological environmental flow methods with MAF, MMF, Q95,Q90,Q50, HFRs, IFRs \& LFRs are used for high, intermediate \& low flow requirements.

\begin{tabular}{|l|l|l|l|l|l|}
\hline $\begin{array}{l}\text { Hydrological } \\
\text { Season }\end{array}$ & $\begin{array}{l}\text { Tennant } \\
\text { method }\end{array}$ & $\begin{array}{l}\text { Tessman } \\
\text { method }\end{array}$ & $\begin{array}{l}\text { Smakhtin } \\
\text { method }\end{array}$ & $\begin{array}{l}\text { Q90_Q50 } \\
\text { method }\end{array}$ & VMF method \\
\hline $\begin{array}{l}\text { Low-flow } \\
\text { requirements(LFRs) }\end{array}$ & $0.2 \mathrm{MAF}$ & MMF & Q90 & Q90 & $0.6 \mathrm{MMF}$ \\
\hline $\begin{array}{l}\text { High-flow } \\
\text { requirements(HFRs) }\end{array}$ & $0.4 \mathrm{MAF}$ & $0.4 \mathrm{MMF}$ & $0-0.2 \mathrm{MAF}$ & Q50 & $0.3 \mathrm{MMF}$ \\
\hline $\begin{array}{l}\text { Intermediate-flow } \\
\text { requirements(IFRs) }\end{array}$ & - & $0.4 \mathrm{MAF}$ & - & - & $0.45 \mathrm{MMF}$ \\
\hline
\end{tabular}

For Smakhtin method, IfQ90>30\%MAF,HFR=0, If 20\%MAF<Q90<30\%MAF,HFR=7\%MAF. If $10 \% \mathrm{MAF}<\mathrm{Q} 90<20 \% \mathrm{MAF}, \mathrm{HFR}=15 \% \mathrm{MAF}$, IfQ90<10\%MAF,HFR=20\%MAF

Once such curve is determined, then converted to actual environmental monthly flow time series in terms of percentage of mean annual run off (MAR). Global Environmental Flow Calculator (GEFC) is a software package which is developed by International Water Management Institute (IWMI,2006). The GEFC uses the shifting technique to estimate EF. The higher the EMC, the more water is to be need for ecosystem maintenance. The six EMCs are used in the calculators ranging from "unmodified" to "critically modified", i.e. EMC A,B,C,D,E\&F. Water resources currently target class of D or above. Each EMC is represented by unique FDC. The best suited EMC for the river to be selected based on expert Judgement.

\section{Results \& discussion}

The average daily flow data series of 24 years (1991-92 to2014-15) at Jobra gauging staion, Mahanadi river was used to develop FDC and to generate flow requirements corresponding to different levels of ecosystem values, i.e. from unmodified natural condition to critically modified condition. 


$$
\begin{aligned}
& \text { A: Natural } \\
& \text { B: Slightly Modifiedl } \\
& \text { D: Largely Modified } \\
& \text { E: Seriously Modified } \\
& \text { F: Critically Modified }
\end{aligned}
$$$$
\text { DEFAULT ENVIRONMENTAL MANAGEMENT CLASSES }
$$

- Pristine Condition Minot

- Largely Intact Biodiversity and Habitats Despite Water Resources Development and/or Basin Modifications The Habitats and Dynamics of the Biota have Been Disturbed, but Basic Ecosystem Functions are Still Intact. Alien Species Present.

- Large changes in natural habitat, biota and basic ecosystem functions have occurred. A clearly lower than expected species richness. Much lowered presence of intolerant species. Alien species prevail. - Habitat diversity and availability have declined. A strikingly lower than expected species richness. Only tolerant species remain. Indigenous species can no longer breed. Alien species have invaded the ecosystem Modifications have reached a critical level and ecosystem has been completely modified with almost total loss of natural habitat and biota. In the worst case, the basic ecosystem functions have been destroyed and the changes are irreversible.

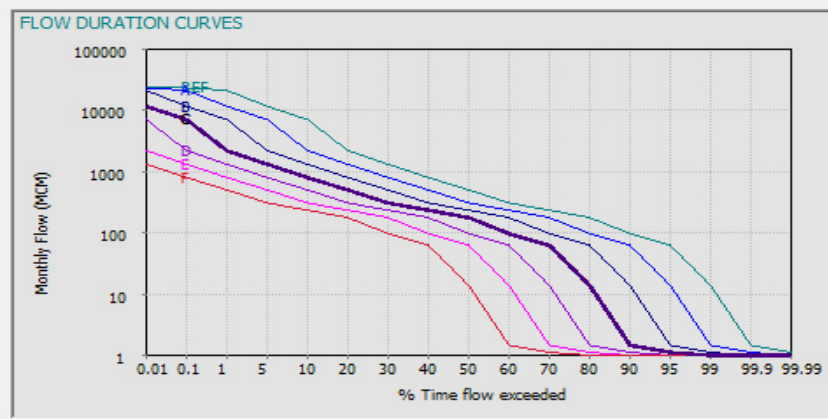

Figure 2 : Flow Duration Curves of Environmental flows of default EMC A,B,C,D,E,F.

The calculator estimated in Figure-2, an average annual EF allocation of $123 \mathrm{~m} 3 / \mathrm{sec}$ (equivalent to $16.6 \%$ of natural MAR), for EMC $\mathrm{C}$ river i.e. water released from the Jobra barrage to maintain the D/S stretch

\begin{tabular}{|c|c|c|c|c|c|c|c|}
\hline $\begin{array}{l}\text { Hydrologic-al } \\
\text { season }\end{array}$ & $\begin{array}{l}\text { Tennant } \\
\text { method }\end{array}$ & $\begin{array}{l}\text { Tessman } \\
\text { method }\end{array}$ & $\begin{array}{l}\text { Smakhti-n } \\
\text { method }\end{array}$ & $\begin{array}{l}\text { Q90_Q50 } \\
\text { method }\end{array}$ & $\begin{array}{l}\text { VMF } \\
\text { method }\end{array}$ & $\begin{array}{l}\text { FDC } \\
\text { method } \\
(\mathrm{GEFC})\end{array}$ & $\begin{array}{l}\text { Average of } \\
\text { EFR results }\end{array}$ \\
\hline $\begin{array}{l}\text { Average } \\
\text { LFR }\left(\mathrm{m}^{3} / \mathrm{sec}\right)\end{array}$ & 148.2 & 142.4 & 37 & 36 & 85.5 & 23.6 & 79 \\
\hline $\begin{array}{l}\text { LFR in \% of } \\
\text { Low flow }\end{array}$ & $104.4 \%$ & $100.3 \%$ & $26.1 \%$ & $25.4 \%$ & $60.2 \%$ & $16.6 \%$ & $56 \%$ \\
\hline $\begin{array}{l}\text { Average } \\
\operatorname{HFR}\left(\mathrm{m}^{3} / \mathrm{sec}\right)\end{array}$ & 296.4 & 928.5 & 149 & 194 & 582 & 322 & 412 \\
\hline $\begin{array}{l}\text { HFR in } \% \text { of } \\
\text { High flow }\end{array}$ & $15.3 \%$ & $47.9 \%$ & $7.7 \%$ & $10 \%$ & $30 \%$ & $16.6 \%$ & $21 \%$ \\
\hline $\begin{array}{l}\text { Average } \\
\operatorname{EFR}\left(\mathrm{m}^{3} / \mathrm{sec}\right)\end{array}$ & 198 & 404 & 74 & 89 & 251 & 123 & 190 \\
\hline $\begin{array}{l}\text { EFR in \% of } \\
\text { MAF }\end{array}$ & $26.7 \%$ & $54.6 \%$ & $10 \%$ & $12 \%$ & $33.9 \%$ & $16.6 \%$ & $26 \%$ \\
\hline $\begin{array}{l}\text { Average(LFR- } \\
\text { HFR) in } \%\end{array}$ & (104-15) & $(100-48)$ & $(26-7.7)$ & $(25-10)$ & $(60-30)$ & $16.6 \%$ & $(56-21) \%$ \\
\hline
\end{tabular}
of the Mahanadi river, in moderate condition and to keep basic ecosystem function intact.

Table 3. Computation of annual average environmental flow requirements (EFRs) by various methods corresponding to study area.

The EFR, LFR, \& HFR are expressed as a percentage of mean annual discharge of river in natural condition, mean annual low-flow \& mean annual high-flow respectively. 


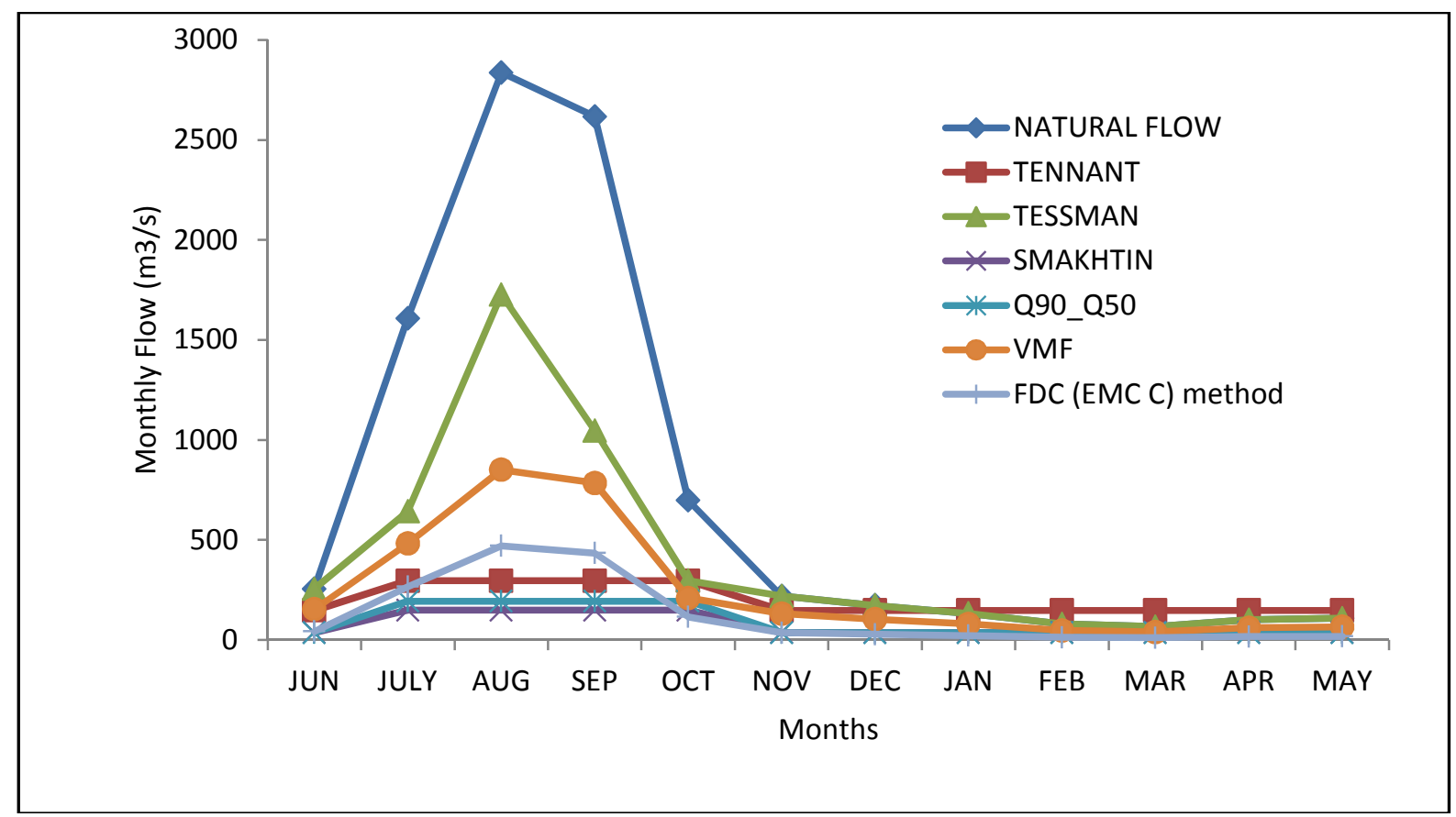

Figure 3:Comparison of EF methods with natural flow.

The results indicate the overall annual average Environmental flow requirements (EFRs) is $190 \mathrm{~m} 3 / \mathrm{sec}$ equivalent to $26 \%$ of MAF (Table-3,Fig-3) and on average low-flow requirements is $79 \mathrm{~m} 3 / \mathrm{sec}$ equivalent to $56 \%$ of mean low flow, while high-flow requirements is $412 \mathrm{~m} 3 / \mathrm{sec}$ equivalent to $21 \%$ of mean high flow. Percentage of Low flow requirements are normally higher than high flow requirements, as the low flow season is longer than four months. The correlation between the calculated EFRs with the six selected methods are shown in Figure-4. From the figure all the simulated EFRs were highly correlated with calculated EFRs. The FDC method, VMF method and Tessman method recorded the highest correlation co-efficient $\left(\mathrm{R}^{2}=0.92\right.$ above $)$, while the Smakhtin, Q90_Q50 \& Tennant methods showed a correlation $\left(\mathrm{R}^{2}=0.75\right)$. The low flow index 7Q10 (7 day mean flow obtained in 10 year return period) flow was calculated using 7 daily mean flow data of 24 hydrological years (1991-92 to 2014-15). In 7Q10 flow duration curve the EFRs value is 5.7m3/sec, which is equivalent to $0.77 \%$ of MAF. This flow rate showing clearly is far less than other above mentioned methods \& this method can be applied for determination of flow rate for habitat protection during drought condition. Lastly in WQAA method (CWC, 2007) the minimum flow calculated is $11 \mathrm{~m} 3 / \mathrm{sec}$, which is equivalent to $1.5 \%$ of MAF \& one flushing flow is $2496 \mathrm{~m} 3 / \mathrm{sec}$, to be released in high flow season. 

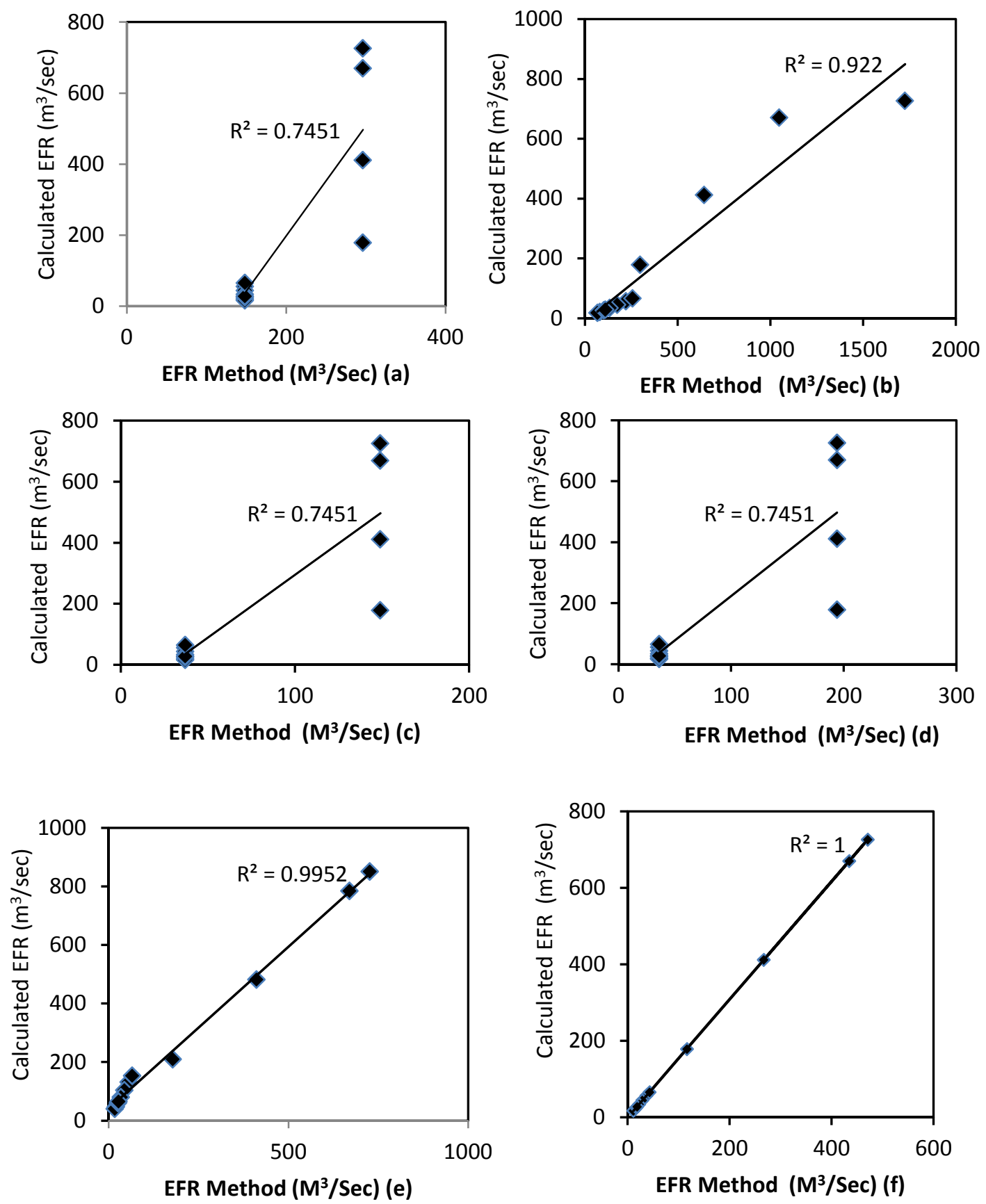

Figure 4: Relation between the monthly calculated EFRs \& the locally calculated EFRs.(a) Tennant method (b) Tessman method (c) Smakhtin method (d) Q90_Q50 method (e) Variable monthly flow (VMF) method (f) FDC(shifting)method for EMC C. In each sub figure, each dot represents EFRs for one month for the case study.

\section{Conclusion}

In the present study six different hydrological environmental flow methods have been applied \& recommended the Environmental flows requirements is $190 \mathrm{~m} 3 / \mathrm{sec}$, which is equivalent to $26 \%$ of MAF and the range of EFRs varies from $79 \mathrm{~m} 3 / \mathrm{sec}$ to $412 \mathrm{~m} 3 / \mathrm{sec}$, which is equivalent to $21 \%$ to $56 \%$ of Low Flows \& High Flows respectively, with one flushing flow $2496 \mathrm{~m} 3 / \mathrm{sec}$ to be released in October month for maintenance of river ecosystem. The range of flow is necessary as High flows important for channel maintenance, bird breeding, algae control, wetland flooding etc; Moderate flows important for fish migration, cycling of organic matter from river banks and Low flows for fish spawning, water quality maintenance \& the use by local people for 
maintaining fair ecological condition. On average Smakhtin method and Q90_Q50 method resulted the lowest EFRs i.e.10\% of MAF and 12\% of MAF respectively. The VMF method resulted EFRs on average $34 \%$ of MAF, which is higher than the Tennant method (27\% of MAF) \& lower than Tessman method (43\% of MAF).The FDC method resulted $16.6 \%$ of MAF for EMC C (moderately modified) condition of river,30.8\% of MAF for EMC B (slightly modified) condition of river \& $57.9 \%$ of MAF for EMC A (natural) condition of river for maintaining basic function of river ecosystem at each level of river towards the Bay of Bengal. From the analysis the VMF method, Tessman method and FDC method showed good correlation with calculated EFRs from case study and these three methods also recommended especially in case of variable flow regimes. The main aim of this study is to ensure the minimum value of flow at any circumstances to avoid any degradation of river ecosystem and if the excess water is stored, then that can be used further for the expansion of irrigation land, in industries, hydropower sector, recreation and many more.

\section{Acknowledgements}

The authors are thankful to Water Resources Department, Odisha for providing data for this study. The authors are also thankful to Nishadi Eriyagama, Water Resources Engineer, International Water Management Institute (IWMI), Colombo, Srilanka for providing the GEFC software.

\section{References}

1. Acreman M, Dunbar MJ.(2004).Defining environmental river flow requirements-a review. Hydrology \& Earth system Sciences 8(5):861-876.

2. Davis R, Hirji R.(2003). Environmental flows: Concept and methods. Water Resources and Environment Technical Note C1.World Bank, Washington. DC.

3. Durbude DG, Jain CK, Singh O.(2014). Assessment of E-flows for a river in Southern India using Hydrological Index methods. Journal of Indian Water Resources Society 34(3).

4. Jha R, Sharma KD, Singh VP.(2008). Critical Appraisal of Methods for the Assessment of Environmental Flows and their Application in two river systems of India. KSCE Journal of Civil Engineering 12(3):213219.

5. Joshi KD, Jha DN, Alam A.(2014).Environmental Flow requirements of River Sone: Impacts of low discharge on fisheries. Current Science 107(3):478-488.

6. Paster AV, Ludwig F, Biemans H, Hoff H.(2014). Accounting for environmental flow requirements in global water assessments. Hydrol Earth System Science 18:5041-5059.

7. Smakhtin VU, Shilpakar RL, Hughes DA.(2006).Hydrology-based assessment of environmental flows:an example from Nepal. Hydrological Sciences-Journal-des Sciences Hydrologiques 51(2).

8. Smakhtin VU, Anupthas M.(2006)-"An assessment of environmental flow requirements of Indian river Basins. IWMI Research Report 107.

9. Smakhtin VU, Eriyagama N.(2008).Developing a software package for global desktop assessment of environmental flows. Environmental Modelling \&Software 23(12):1396-1406.

10. Tennant DL,(1976).Instream Flow Regimes for Fish, Wildlife, Recreation and Related Environment Resources.Fisheries 1(4):6-10.

11. Tharme RE.(2003). A global perspective on environmental flow assessment: emerging trends in the development and application of environmental flow methodologies for rivers. River Research and Applications 19:397-441. 